\title{
HYGIENIC SUBSTANTIATION OF NECESSITY FOR MONITORING IN THE ENVIRONMENTAL OBJECTS OF SDHI FUNGICIDES CONSIDERING THEIR POSSIBLE IMPACT ON THE THYROID GLAND
}

DOI: 10.36740/WLek202009219

\author{
Anna M. Antonenko ${ }^{1}$, Bohdan I. Shpak², Olena P. Vavrinevych'1, Sergii T. Omelchuk' ${ }^{1}$, Tetiana I. Zinchenko ${ }^{1}$ \\ 'BOGOMOLETS NATIONAL MEDICAL UNIVERSITY, KYIV, UKRAINE \\ 2DEPARTMENT OF REGISTRATION AND REGULATION OF «SYNGENTA» LLC, KYIV, UKRAINE
}

\begin{abstract}
The aim: Was hygienic substantiation of necessity for monitoring in the environmental objects of SDHI fungicides considering their possible impact on the thyroid gland. Materials and methods: To test the proposed selection criteria for hygienic monitoring of pesticides that affect the thyroid gland, we evaluated 4 new SDHI fungicides from the chemical class of pyrazolecarboxamides (isopyrazam, pentiopyrad, sedaxan, fluxapyroxad).

Results: Based on the results obtained, all studied compounds are assigned to the second pesticide group, hygienic monitoring of which is desirable but not required. This is due, on the one hand, to their low toxicity, to the other, to low environmental sustainability.

Conclusions: It was shown, that compared to other classes of pesticides, the studied are much less dangerous in terms of groundwater contamination.
\end{abstract}

KEY WORDS: fungicides, selection criteria, hazard class, thyroid gland, monitoring

Wiad Lek. 2020;73(9 p. II):2000-2003

\section{INTRODUCTION}

Despite their popularity and widespread use, pesticides pose a serious risk to human health not only when mixing and applying pesticides or working in cultivated fields, but in the consumption of food and water containing pesticide residues $[1,2]$. The risk assessment for the population when consuming food containing pesticide residues is mandatory in the US and European countries $[3,4]$. In Ukraine, when conducting state tests of new pesticide formulations, a risk assessment is carried out only for agricultural workers and taking into account just possible inhalation and skin contact with pesticide compounds.

In the countries of the European Union and the USA, risk assessment techniques for non-professional contingents have long been tried and actively used [3-7]. Recommendations for such monitoring have also been developed in Ukraine in recent years [8]. The vast majority of such monitoring models existing in Ukraine and in the world do not include assessment of specific indicators for pesticides that may affect the thyroid gland.

Given the level of endocrine pathology in the world, and in particular the prevalence of thyroid disease [8-11], the introduction of such techniques is relevant, timely and necessary.

\section{THE AIM}

The purpose was hygienic substantiation of necessity for monitoring in the environmental objects of fungicides succinate-dehydrogenase inhibitors (SDHI), considering their possible impact on the thyroid gland.

\section{MATERIALS AND METHODS}

Before, we have improved the pesticide monitoring system [8], considering their possible effect on the functioning of the thyroid gland [12], namely:

1. A point evaluation of the selection criteria for monitoring studies was proposed;

2. Additional (groundwater and surface water contamination index (LEACH), integral pesticide contaminated water consumption hazard index (IPCWCI), integral pesticide contaminated food consumption hazard index (IPCFCI) were proposed;

3. Specific criteria (influence on thyroid gland as target organ, severity of pesticide induced tyrosinemia (plasma tyrosine level, $\mathrm{nmol} / \mathrm{ml}$ )).

After adding all points received, the need for monitoring is evaluated as follows: for a total of 11-16 points - monitoring is not required; $17-27$ points - monitoring is desirable; 28-38 - mandatory monitoring; 39-44 - pesticide application should be prohibited [12].

To test the proposed selection criteria for hygienic monitoring of pesticides that affect the thyroid gland, we evaluated 4 new SDHI fungicides from the chemical class of pyrazolecarboxamides (isopyrazam, pentiopyrad, sedaxan, fluxapyroxad).

\section{RESULTS AND DISCUSSION}

Environmental monitoring models that exist in Ukraine today $[8,13]$ provide for observations of the state of the 
Table I. Selection of investigated fungicides for hygienic monitoring

\begin{tabular}{|c|c|c|c|c|}
\hline \multirow{2}{*}{ Criteria } & \multicolumn{4}{|c|}{ Index value (score in points) } \\
\hline & isopyrazam & pentiopyrad & sedaxan & fluxapyroxad \\
\hline Allowable daily dose (ADD), mg/kg & $0,01(2)$ & $0,1(1)$ & $0,1(1)$ & $0,02(2)$ \\
\hline $\begin{array}{c}\text { Class of hazard according to State } \\
\text { Standards 8.8.1.002-98 }\end{array}$ & $2(3)$ & $3(2)$ & $3(2)$ & $3(2)$ \\
\hline $\begin{array}{l}\text { Impact on the thyroid gland as a } \\
\text { target organ }\end{array}$ & $\begin{array}{c}\text { weak effect in } \\
\text { animal experiments } \\
(2)\end{array}$ & $\begin{array}{l}\text { weak effect in animal } \\
\text { experiments ( } 2)\end{array}$ & $\begin{array}{l}\text { weak effect in animal } \\
\text { experiments }(2)\end{array}$ & $\begin{array}{l}\text { weak effect in animal } \\
\text { experiments ( } 2)\end{array}$ \\
\hline $\begin{array}{l}\text { The severity of pesticide-induced } \\
\text { tyrosinemia (plasma tyrosine levels, } \\
\mathrm{nmol} / \mathrm{ml} \text { ) }\end{array}$ & $<300(1)$ & $<300(1)$ & $<300(1)$ & $<300(1)$ \\
\hline Half-life period $\left(\mathrm{DT}_{50}\right)$ in soil, day & $12,5(2)$ & $3,0(1)$ & $12,5(2)$ & $11,3(2)$ \\
\hline Half-life period $\left(\mathrm{DT}_{50}\right)$ in water, day & $2,3(1)$ & $9,9(2)$ & $14,0(3)$ & $4,4(1)$ \\
\hline Half-life period $\left(\mathrm{DT}_{50}\right)$ in plants, day & $3,6(1)$ & $2,5(1)$ & $2,8(1)$ & $3,8(1)$ \\
\hline $\begin{array}{l}\text { the Groundwater and Surface Water } \\
\text { Pollution Index (LEACH), units }\end{array}$ & $0,0028(1)$ & $0,0214(2)$ & $0,0342(2)$ & $0,0534(3)$ \\
\hline $\begin{array}{l}\text { Screening of maximum pesticide } \\
\text { concentration in groundwater } \\
(\mathrm{SCl}-\mathrm{GROW}), \mu \mathrm{g} / \mathrm{l}\end{array}$ & $5,5 \times 10^{-3}(2)$ & $5,4 \times 10^{-3}(2)$ & $3,4 \times 10^{-2}(2)$ & $2,6 \times 10^{-3}(2)$ \\
\hline $\begin{array}{l}\text { Integral index of contaminated water } \\
\text { consumption hazard (IICWCH), points }\end{array}$ & $4(1)$ & $5(2)$ & $6(2)$ & $5(2)$ \\
\hline $\begin{array}{l}\text { Integral index of contaminated food } \\
\text { consumption hazard (IICFCH), points }\end{array}$ & $7(3)$ & $6(2)$ & $8(3)$ & $8(3)$ \\
\hline Total score & 19 & 18 & 22 & 21 \\
\hline
\end{tabular}

environment (air, land waters, coastal waters, soil), and the level of pollution. The implementation of these functions is entrusted to the Ministry of Energy and Environmental Protection and other central executive organizations, which are the subjects of the state environmental monitoring system, as well as to the enterprises, institutions and organizations whose activities lead to or may worsen the environment [13].

Our monitoring system model proposes a risk assessment for non-professional contingents whose organisms can be exposed with pesticides mainly by oral intake with drinking water and food. In addition, it lays down specific criteria for pesticide monitoring that affect the thyroid gland, which is extremely relevant today for many countries in the world [10-11].

Such hygienic monitoring of pesticides that affect the thyroid gland requires, first of all, areas with intensive agriculture. In Ukraine, for example, such regions as Vinnytsia, Cherkasy, Poltava, Kherson, Odessa, Mykolaiv. However, in other areas such monitoring is desirable, as chemical plant protection products are being actively introduced into world agriculture, including privately owned farms that are mostly uncontrolled, which complicates the determination of pesticide application volumes in them.

According to the toxicological criteria, all tested compounds are low- and moderately toxic: relatively high allowable daily doses, 2-3 hazard class.
In soil and climatic conditions of Eastern, Southern and partly Central Europe, including Ukraine, the investigated fungicides are unstable in environmental objects and agricultural raw materials $[14,15]$.

It was established that in soil-climatic conditions of Ukraine the risk of groundwater contamination by all investigated fungicides (isopyrazam, pentiopyrad, sedaxan, fluxapyroxad) is low, and their maximum possible concentrations in groundwater are insignificant and much lower than allowable. This is due to the low percentage of active ingredients in the fungicide formulations and indicates the relative safety for human health of drinking of water in which the test compounds may be present [14].

Given that, isopyrazam, pentiopyrad, sedaxan, fluxapyroxad based formulations are used predominantly for the treatment of cereals (consumed after purification and heat treatment), the risk to humans of consuming contaminated products is also relatively low [16].

Each of proposed criteria was evaluated according to the proposed scale in points and their sum was calculated (Table I).

Given that, isopyrazam, pentiopyrad, sedaxan, fluxapyroxad based formulations are used predominantly for the treatment of cereals (consumed after purification and heat treatment), the risk to humans of consuming contaminated products is also relatively low [16]. 
Compared to other classes of pesticides, the studied are much less dangerous in terms of groundwater contamination. For example, herbicides that have been successfully used in Ukrainian and world agriculture for many years, benzoic acid derivative - dicamba, sulphonyl urea - nicosulfuron, and strobilurin class fungicide - azoxystrobin are characterized by high risk of groundwater contamination $[17,18]$. Similarly, pymetrozine is a fungicide that belongs to a relatively new chemical class of fungicides, namely pyridine azomethrines [17].

There may be several reasons. For example, low toxicity, low environmental stabilityю Fungicides from the studied classes do not lead to the development of tyrosinemia. This effect is observed in the herbicides of 4-hydroxyphenylpyruvate dioxygenase inhibitors and the tetramic and tetronic acid-like insecticides $[19,20]$.

\section{CONCLUSIONS}

Based on the results obtained, all studied compounds are assigned to the second pesticide group, hygienic monitoring of which is desirable but not required. This is due, on the one hand, to their low toxicity, to the other, to low environmental sustainability.

\section{REFERENCES}

1. Soares W.L., Porto M.F.D. Estimating the social cost of pesticide use: An assessment from acute poisoning in Brazil. Ecolological Economics. 2009;68:2721-2728.

2. Lewis K., Tzilivakis J. Review of the published exposure data to pesticides for residents and bystanders, and for environmental risk assessment: Final report Agriculture and Environment Research Unit. EFSA Supporting publication. University of Hertfordshire. 2017: 1204.

3. Overview of Risk Assessment in the Pesticide Program. US EPA. https:// www.epa.gov/pesticide-science-and-assessing-pesticide-risks/ overview-risk-assessment-pesticide-program.

4. European Food Safety Authority. Exposure to pesticides data for residents and bystanders, and for environmental risk assessment. https://data. europa.eu/euodp/data/dataset/exposure-to-pesticides-data-forresidents-and-bystanders-and-for-environmental-risk-assessment.

5. Overview of Risk Assessment in the Pesticide Program. USEPA. https:// www.epa.gov/pesticide-science-and-assessing-pesticide-risks/ overview-risk-assessment-pesticide-program.

6. Regulating Pesticides through Risk Assessment. National Pesticide Information Center. http://npic.orst.edu/reg/risk.html.

7. GUIDANCE OF EFSA: Guidance on the assessment of exposure of operators, workers, residents and bystanders in risk assessment for plant protection products. European Food Safety Authority (EFSA) Journal. 2014;12(10):3874-3924.

8. Vavrinevy'ch 0.P. Gigiyenichne obg 'runtuvannya kry teriyiv vidboru dlya provedennya monitory'ngu fungicy'div v agropromy slovomu kompleksi Ukrayiny` [Hygienic substantiation of selection criteria for monitoring of fungicides in the agro-industrial complex of Ukraine]. Environment \& Health. 2019;1:4-9. doi.org/10.32402/ dovkil2019.01.004. (in Ukrainian).

9. Goodarzi E., Moslem A., Feizhadad H. et al. Epidemiology, incidence and mortality of thyroid cancer and their relationship with the human development index in the world: An ecology study in 2018. Adv Hum
Biol. 2019;9:162-167. doi: 10.4103/aihb.aihb_2_19.

10. Antonenko A.M., Vavrinevych O.P., Korshun M.M. et al. Hygienic assessment of the effects of pesticides application on adult population morbidity with thyroid gland diseases. Wiadomości Lekarskie. 2018;71(2):353-357.

11. Antonenko A.M., Korshun M.M., Vavrinevych O.P. et al. Epidemiologic evaluation of thyroid diseases morbidity of Ukrainian adult population from 2000 to 2013. International Journal of Medicine and Medical Research. 2018;4(1):52-59.

12. Antonenko A.M., Vavrinevych 0.P., Omelchuk S.T. et al. Improvement of the monitoring system in the environment of pesticides affecting thyroid gland. Environment \& Health. 2019;4:13-18. doi.org/10.32402/ dovkil2019.04.012.

13. Environmental monitoring of the environment. The official portal of the of Energy and Environmental Protection. https://menr.gov.ua/content/ ekologichniy-monitoring-dovkillya.html.

14. Antonenko A.M., Vavrinevych O.P., OmelchukS.T. et al. Prediction of pesticide risks to human health by drinking water extracted from underground sources. Georgian Medical News. 2015;7-8(244-245):99-106.

15. PPDB: Pesticide Properties Data Base access:http://sitem.herts.ac.uk/ aeru/footprint/en/.

16. Antonenko A.M., Vavrinevy 'ch O.P., Omel 'chuk S.T. et al. Gigiyenichne obg 'runtuvannya modeli prognozuvannya nebezpeky dlya lyudy 'ny' pry` vzhy vanni sil’s'kogospodars`ky`x produktiv kontaminovany`x pesty 'cy 'damy' (na pry 'kladi fungicy 'div klasu pirazolkarboksamidiv) [Hygienic justification of the model of prediction of danger to humans when using agricultural products contaminated with pesticides (for example, pyrazolecarboxamide class fungicides)]. The unity of science. 2018:46-48. (in Ukrainian).

17. Ruda T.V., Korshun M.M. Prognozuvannya nebezpechnosti zabrudnennya g runtu ta pidzemny $x$ vod pry`zastosuvanni pesty`cy div rizny` $x$ klasiv dlya zaxy`stu olijny ' $x$ kul' tur v g'runtovo-klimaty`chny`x umovax Ukrayiny' [Prediction of the danger of soil and groundwater contamination in the application of pesticides of different classes for the protection of oilseeds in soil and climatic conditions of Ukraine]. Modern problems of toxicology, food and chemical safety. 2017;1-2:77-78. (in Ukrainian).

18. Stavnichenko P.V., Novohatska L.O., Antonenko A.M. et al. Assessment of ecotoxicological hazard and risk of groundwater contamination with different groups of pesticides. Medical perspectives. 2017;22(2):119-125.

19. Antonenko A.M., Blagaia A.V., Vavrinevych O.P. et al. Mechanism of action of 4-hydroxyphenylpyruvate dioxygenase inhibitor herbicide on homoterm animals and humans. Journal of Pre-Clinical and Clinical Research. 2015;9(2):148-153.

20. Antonenko A.M. Osobly 'vosti toksy 'kody 'namiky' ta ocinka nebezpechnosti novogo insekty 'cy'du spiromezifenu [Features of toxicodynamics and risk assessment of a new spiromesifen insecticide]. The unity of science. 2019:57-58. (in Ukrainian).

\section{ORCID and contributionship:}

Anna M. Antonenko: 0000-0001-9665-0646 A, D

Bohdan I. Shpak: 0000-0001-9273-8544 ${ }^{B}$

Olena P. Vavrinevych: 0000-0002-4871-0840 ${ }^{E}$

Sergii S. Omelchuk: 0000-0003-3678-4241 ${ }^{\mathrm{F}}$

Tetiana I. Zinchenko: 0000-0002-3541-9480 ${ }^{\mathrm{C}}$

\section{Conflict of interest:}

The Authors declare no conflict of interest. 


\section{CORRESPONDING AUTHOR}

Anna M. Antonenko

Bogomolets National Medical University

13 Tarasa Shevchenko st., 01601 Kyiv, Ukraine

tel: +380991466331

e-mail: antonenk01985@ukr.net

Received: 09.03 .2020

Accepted: 24.06 .2020

A - Work concept and design, B - Data collection and analysis, C - Responsibility for statistical analysis,

$\mathbf{D}$-Writing the article, $\mathbf{E}$-Critical review, $\mathbf{F}$ - Final approval of the article 